\title{
Diversity of Amphibians and Reptiles in Various Anthropogenic Disturbance Habitats in Nantu Forest, Sulawesi, Indonesia
}

\author{
Mirza Dikari Kusrini*, Luna Raftika Khairunnisa, Aria Nusantara, Agus Priyono Kartono, Lilik Budi \\ Prasetyo, Novi Tri Ayuningrum, Fata Habiburrahman Faz
}

Department of Forest Resources Conservation and Ecotourism, Faculty of Forestry and Environment, IPB University, Academic Ring Road, Campus IPB Dramaga, Bogor, Indonesia 16680

Received June 29, 2020/Accepted November 18, 2020

\begin{abstract}
The Nantu Forest in Gorontalo Province, Sulawesi, Indonesia holds one of the few remaining pristine habitats in the island. The reserve is surrounded by human habituation which provide opportunity to study the impact of forest lost on biodversity. In addition, data on Nantu mostly focused on big mammals, as there is no previous herpetofauna survey at the area. Sampling of amphibian and reptile was conducted in June 2013 and in May-June 2014 using Visual Encounter Survey method, glue traps and transect sampling in seven different sites at the eastern part of Nantu. We categorized four habitat types based on human disturbances: high disturbed habitat (HDH), moderate disturbed habitat $(M D H)$, low disturbed habitat $(\mathrm{LDH})$ and pristine habitat $(P H)$. A total of 680 individual amphibians (4 families; 17 species) and 119 individual reptiles (9 families; 29 species) were recorded. Species richness and species composition for amphibians and reptiles differs according to the level of human disturbances. Low level disturbances habitat demonstrated the highest diversity of amphibians and reptiles, whereas as expected, high distubed habitat showed the lowest diversity. Anthropogenic pressures in forest will decrease species richness of amphibian and reptiles. Although most amphibian and reptiles will be able to persist in low disturbances habitat, forest-dependent species will be lost when pristine forests are disturbed.
\end{abstract}

Keywords: anthropogenic disturbances, biodiversity, herpetofauna, Nantu Wildlife Sanctuary, Sulawesi

*Correspondenceauthor,email: mirza_kusrini@yahoo.com,tel./fax: +62-251-8621947

\section{Introduction}

Tropical forest has long been considered as home for various animals, including endemics. The complex structures of the vegetation provide an important habitat for protection, nesting and foraging for many species, i.e. invertebrates, birds, mammals, and other small vertebrates such as amphibians and reptiles (Williams et al., 2002; DeWalt et al., 2003; Lassau et al., 2005; Bouvet et al., 2016; Bateman \& Merritt, 2020). Amphibian and reptiles, known collectively as herpetofauna, provides an important ecosystem service not only as primary, mid level and top consumers but also for nutrient cycling, biological control, seed dispersal, protein sources (food source), raw materials and medicinal and rituals (Cortes et al., 2014; ValenciaAguilar et al., 2013; Hocking \& Babbit, 2014; de Miranda, 2017). Habitat loss, particularly through deforestation and degradation (anthropogenic pressure), is considered the main factors for global decline in population of amphibians (Stuart et al., 2005) and reptiles (Böhm et al., 2013). Indonesia has the highest loss of forest in the tropics (Margono et al., 2014), mostly by anthropogenic pressures i.e expansions of oil palm plantations, conversions to grassland/shrublands, expansions of small-scale agriculture and small-scale mixed plantations (Austin et al., 2019). It has been postulated that protected areas area has low deforestation rate and therefore able to effectively conserve biodiversity (Chape et al., 2005; Gaveau et al., 2012; Shah \& Baylis, 2015). However, several studies i.e., in Kalimantan showed that protected forests have become increasingly isolated and deforested (Curran et al., 2004; Susanto et al., 2018). Although the areas are legally protected, encroachments are rife in main islands of Indonesia e.g. in Sumatera (Gaveau et al., 2007), Kalimantan (Currant et al., 2004), and Sulawesi (Supriatna et al., 2020). Type of disturbances are also varying, from low level of disturbance (e.g., exploitation of natural resources) to high level of disturbance (e.g., agricultural practices, illegal exctraction of mineral from the soil). Anthropogenic disturbance altering the pristine habitat in Indonesia is undoubtedly affect the distribution and population of amphibian and reptile (Iskandar \& Erdelen, 2006).

Despite known as biodiversity hotspot, Southeast Asia (including Indonesia) is lacking information on biodiversity, distribution and biology of amphibian and reptile compared to the other parts of the world (Iskandar \& Erdelen, 2006; Rowley et al., 2009; Koch, 2011). Undoubtedly many more species of amphibian and reptile are awaiting to be discovered and to be assessed. This hold true because in the tropical regions cryptic species is very common, and thus the 
number of species diversity is underestimated (see Bain et al., 2003; Stuart et al., 2006; Che et al., 2009). Increasing rate of land conversion in Southeast Asia, especially Indonesia (Sodhi et al. 2010), has urgently raise concern on the the need for basic information of biodiversity. Sulawesi Island hold the highest endemic species in Indonesia (Whitten et al., 1987). Although research in this island is limited, various publications on Sulawesi amphibian and reptiles has reported many new species to science (Brown et al., 2000; Howard et al., 2007; Kuch et al., 2007; Hayden et al., 2008; Iskandar et al., 2011, 2014; Howard \& Gillespie, 2017), several of which are needed to be described (Koch, 2011).

Most of the study on the impact of forest loss in Indonesia to wildlife populations refers to big vertebrates i.e. orang utan, tiger, javan warty pig and birds (see Robertson \& Schaik, 2001; Waltert et al., 2005; Semiadi \& Meijaard, 2006; Prabowo et al., 2016; Smith et al., 2018). Sulawesi, part of the Wallacean, were noted for its mixture of western and eastern Indo-Australian Archipelago biotic segments, and its endemism. Understanding the impact of forest loss should also highlight the biodiversity of other un-charismatic species for effective conservation management (Muñoz, 2007) i.e. amphibians and reptiles. The Nantu Wildlife Reserve (31.215 ha) in Gorontalo Province is one of the remaining lowland natural areas in Sulawesi, which are the habitat for several endemics mammals such as babirusa (Babyrousa babyrusa), sulawesi's boar (Sus celebensis), anoa (Bubalus spp.), sulawesi's black macaque (Macaca heckii) and tarsier (Tarsius spectrum). In fact, most of the researches in Nantu were focused on mammals (Clayton, 1996; Clayton et al., 1997 Clayton \& Macdonald, 1999;
Clayton \& Milner-Gulland, 1999; Clayton et al., 2000). Other than mammals, there were only a report on diversity of birds (Arini et al., 2011) and one report highlighting finding of a species of bird (Gulson-Castillo et al., 2018), but none on amphibian and reptiles.

Nantu Forest and the surrounding areas provide an opportunity for studying impact of forest habitat conversion due to agricultural activity for amphibian and reptile communities. In this paper we provide the first herpetological species list of Nantu Forest and analyses the amphibian and reptile community in different type of anthropogenic disturbances.

\section{Methods}

Study areas This study was conducted in the eastern part of Nantu Wildlife Reserve, Gorontalo Province, Sulawesi, Indonesia (N0103'00"-N01 34 '00”; E1251'00”$\left.125^{\circ} 15^{\prime} 00^{\prime \prime}\right)$, which is located within Nantu Forest, and adjacent villages outside the reserve (Figure 1). We adopted level of anthropogenic disturbances based on Moy et al. (2016), with distance to the nearest human habitation and the availability of road access as the main consideration. Our survey locations $(\mathrm{N}=7)$ were categorized into four habitat types: (1) high disturbed habitat (HDH): antropogenically disturbed area with good quality road access, e.g rice paddy fields and the surroundingvillages; (2) moderate disturbed habitat (MDH): sites within $150 \mathrm{~m}$ away from anthropogenically disturbed area with moderate quality road access, e.g., mixed coconut-corn plantations; (3) low disturbed habitat (LDH): sites within $300 \mathrm{~m}$ away from anthropogenicallv disturbed area with onlv walking path

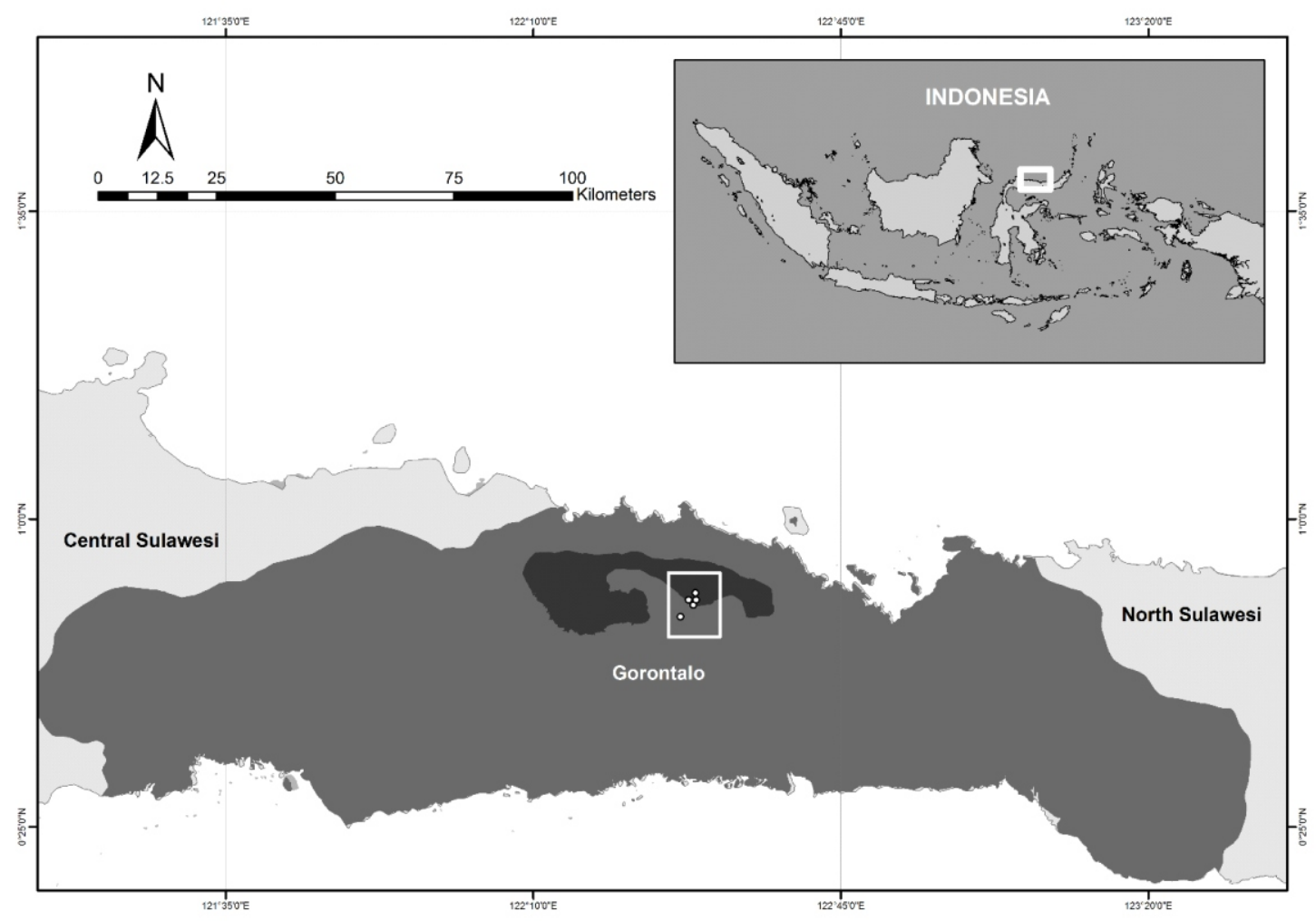

Figure 1 Research location at Nantu Forest and its adjacent areas, Gorontalo Province, Sulawesi. Dark colors represent the whole area of Nantu Forest. White points in squarebox refers to sampling sites. 
access, e.g., secondary forest near the border of the Nantu Reserve (the main human disturbances in this area is the villagers who are harvesting fallen logs for firewood); and (4) pristine habitat $(\mathrm{PH})$, preserved forest inside wildlife reserve, further than $300 \mathrm{~m}$ from an anthropogenically disturbed area with almost no road access. All sites have a minimum distance of $500 \mathrm{~m}$ from each other in order to minimize problems with pseudoreplication.

Data collection Samplings in the above mentioned location to collect data on the number and species of amphibians and reptiles were performed two times, as described below:

1) June 2013

We employed Visual Encounter Survey (VES) with time constrained method (Heyer et al., 1994; McDiarmid et al., 2012) for two weeks. This approach was peformed by by 3-4 persons in each locality from 1900-2400. The searched was repeated the next day (two nights per locality) covering all microhabitats both in terrestrial and aquatic habitats (streams). Ten glue traps $\left(\begin{array}{lll}30 & 30 \mathrm{~cm}\end{array}\right.$ square board) were put each morning in each sites to capture and record small reptiles i.e. skinks.

2) May-June 2014

For three weeks, we conducted search in the same locations as first year sampling, focusing only on aquatic habitats. Nocturnal transect sampling were carried out by 3-4 persons from 1900-2400 along the stream using three transect (100 m length) for each sites, with $100 \mathrm{~m}$ intervals between transect. Searches were made in all possible areas including under leaf litter, logs, branch piles, stones and tree buttresess along the streams, mostly $12 \mathrm{~m}$ from the side of the stream body depending on the thickness of forest.

All individuals we encountered during survey were captured, photographed and identified in the field and returned to the field, except for unidentified specimens or with taxonomic uncertainty which were collected and preserved using 70\% alcohol for re-examination in lab to confirm their identities. Identification were conducted using papers and reports on Sulawesi frogs (i.e Brown \& Iskandar, 2000; Iskandar et al., 2011a; Iskandar et al., 2014; Kusrini et al., 2015), or reptiles (i.e. Brown et al., 2000, de Lang \& Vogel, 2006; Howard \& Gillespie, 2007; Howard et al., 2007; Hayden et al., 2008; Linkem et al., 2008; Kuch et al., 2007; Koch, 2008; Iskandar et al., 2011b; Riyanto et al., 2016). All specimens were deposited in Museum Zoologicum Bogoriense (MZB). We follow Frost (2018), de Lang and Vogel (2006), and the reptile database (Uetz \& Hosek, 2014) for amphibians, snakes, and reptile's nomenclature, respectively.

Data analysis We pooled data from first year and second year of sampling and generated a table with list of the species, incorporate information on habitat use, relative abundance, and its conservation status following IUCN Red list of Threatened Species (IUCN, 2020). We analyzed diversity of amphibian and reptile communities in different type of anthropogenic disturbances using Shannon diversity indices (H), equitability (evenness; E) (Magurran, 2010) and predicted the number of species in each type of habitat following Chao et al. (2009). Student's $t$-test was used to assess the significance of differences of diversity between level of disturbances. Data analysed were based on results from VES in 2013 and transect sampling in 2014. We omitted glue traps data as it only resulted in low number of species captured which also found during VES and transect sampling. We also ran cluster analyses to construct a dendogram for amphibian and reptile communities using Bray-Curtis similarity Index and single linkage method (Bloom, 1981). All analyses were performed using Paleontological Statistics (PAST) version 3.21 (Hammer, 2018).

\section{Results and Discussion}

We recorded 680 individuals of amphibian representing 17 species and 119 individuals of reptile representing 29 species (Table $1 \&$ Table 2). Species accumulation curves for all locations showed that after 15 days, number of amphibian richness increases very slowly with continued sampling effort, whereas at the same time for reptiles there is a higher increase of species number with continued sampling effort (Figure 2). These result is similar with the estimation of species richness based on Chao-1 (Table 3). We recorded two unidentified species of skinks (Sphenomorphus sp.) and only assigned identification to genus level pending deeper taxonomic analyses to establish the identity of the species. One species has a significant resemblance to a known species but it is still uncertain, thus a $c f$ is put between genus name and species (Lamprolepis cf smaragdina). One species of amphibian, found with tadpoles in her stomach was assigned only as genus level during survey (Limnonectes sp). All amphibians were recorded duing nocturnal survey and $7.56 \%$ of reptiles were taken from glue traps which consisted of 5 species: Emoia caeruleocauda, Eutropis rudis, Hemiphyllodactylus typus, Lipinia quadrivittata, and Lygosoma bowringii. All reptiles taken from glue traps were also recorded during nocturnal survey.

While the majority of amphibians recorded from this study are categorized as least concern (LC), three species are listed as vulnerable (VU: Chalcorana macrops, Limnonectes heinrichi and Rhacophorus monticola) and one species is not assessed (Polypedates iskandari). Interestingly, most species of reptiles recorded in this study $(75.6 \%)$ fell into none of IUCN categories because they have not been evaluated to date. Two species of reptiles are listed as Data Deficient (Ptyas dipsas and Rhabdophis chrysargoides) and 6 species are listed as LC; 70.6\% (12 species) of the total amphibians were endemics and only $20.7 \%$ (6 species) of reptiles were endemic. Additionally, the two unidentified species of Sphenomorphus could be new to science. Given the high endemism in Sulawesi, it is possible that they only distributed in the island. Suprisingly, the percentage of endemics species and relative abundance of endemic amphibian tends to decrease along disturbance gradient. This pattern is also demonstrated in reptiles, except for the pristine habitat (Table 3).

Individual rarefaction values for amphibian and reptiles showed that the highest number of individual and highest species number was observed in low disturbance habitat. On the other hand, for amphibian the second highest number of 
Table 1 Amphibian species of the Nantu Forest and its adjacent areas, Gorontalo Province. IUCN Red List categories: CR $=$ Critically Endangered; EN = Endangered; VU = Vulnerable; NT = Near Threatened; LC = Least Concern; DD = Data Deficient; NE = not evaluated by the IUCN (IUCN 2020); Endemic [Y(yes)/N(no)/?(not known)] = Sulawesi endemic; Habitat category: $\mathrm{PH}=$ Pristine habitat; $\mathrm{LDH}=$ Low disturbed habitat; $\mathrm{MDH}=$ moderate disturbance habitat (mixed coconut-corn plantation); $\mathrm{HDH}=$ high disturbed habitat (Rice Field and Village).

\begin{tabular}{|c|c|c|c|}
\hline Species & $\begin{array}{l}\text { IUCN } \\
\text { red list } \\
\text { category }\end{array}$ & Endemic & Habitats category \\
\hline \multicolumn{4}{|l|}{ Bufonidae } \\
\hline Duttaphrynus melanostictus (Schneider, 1799) & $\mathrm{LC}$ & $\mathrm{N}$ & $\mathrm{HDH}, \mathrm{MDH}, \mathrm{LDH}$ \\
\hline Ingerophrynus celebensis (Günther, 1859) & $\mathrm{LC}$ & $\mathrm{Y}$ & MDH, LDH, PH \\
\hline \multicolumn{4}{|l|}{ Dicroglossidae } \\
\hline Fejervarya cancrivora (Gravenhorst, 1829) & $\mathrm{LC}$ & $\mathrm{N}$ & $\mathrm{HDH}, \mathrm{MDH}, \mathrm{LDH}$ \\
\hline Fejervarya limnocharis (Gravenhorst, 1829) & $\mathrm{LC}$ & $\mathrm{N}$ & MDH, LDH, PH \\
\hline Limnonectes grunniens (Latreille, 1801) & $\mathrm{LC}$ & $\mathrm{N}$ & $\mathrm{MDH}, \mathrm{LDH}, \mathrm{PH}$ \\
\hline Limnonectes heinrichi (Ahl, 1933) & VU & $\mathrm{Y}$ & $\mathrm{MDH}, \mathrm{LDH}, \mathrm{PH}$ \\
\hline $\begin{array}{l}\text { Limnonectes larvaepartus Iskandar, Evans \& } \\
\text { McGuire, } 2014\end{array}$ & $\mathrm{LC}$ & $\mathrm{Y}$ & MDH, LDH, PH \\
\hline Limnonectes modestus (Boulenger, 1882) & $\mathrm{LC}$ & $\mathrm{N}$ & MDH, LDH, PH \\
\hline Occidozyga celebensis (Smith, 1927) & $\mathrm{LC}$ & $\mathrm{Y}$ & MDH, LDH, PH \\
\hline Occidozyga semipalmata Smith, 1927 & $\mathrm{LC}$ & $\mathrm{Y}$ & MDH, LDH \\
\hline \multicolumn{4}{|l|}{ Ranidae } \\
\hline Chalcorana macrops (Boulenger, 1897) & VU & Y & MDH, LDH, PH \\
\hline Chalcorana mocquardii (Werner, 1901) & $\mathrm{LC}$ & $\mathrm{Y}$ & LDH, PH \\
\hline Hylarana celebensis (Peters, 1872) & $\mathrm{LC}$ & $\mathrm{Y}$ & $\mathrm{MDH}, \mathrm{LDH}, \mathrm{PH}$ \\
\hline \multicolumn{4}{|l|}{ Rhacophoridae } \\
\hline $\begin{array}{l}\text { Polypedates iskandari Riyanto, Mumpuni, \& } \\
\text { Mcguire, } 2011\end{array}$ & NA & Y & MDH, LDH \\
\hline Rhacophorus edentulus Mueller, 1894 & $\mathrm{LC}$ & Y & $\mathrm{PH}$ \\
\hline Rhacophorus georgii Roux, 1904 & $\mathrm{LC}$ & $\mathrm{Y}$ & $\mathrm{LDH}, \mathrm{PH}$ \\
\hline Rhacophorus monticola Boulenger, 1896 & VU & Y & $\mathrm{PH}$ \\
\hline
\end{tabular}

individual was recorded by moderate disturbance habitat, whilst for reptiles was pristine habitat (Figure 3). In general, species richness and diversity differ between habitats. High modified landscape with high anthropogenic pressure has lowest amphibian and reptile diversity compared to other habitat (Table 3).

There was a significant differences of Shannon diversity indices for amphibian between $\mathrm{HDH}$ with $\mathrm{LDH}\left(t_{(7)}=-5.31\right.$, $p<0.001), \mathrm{MDH}\left(t_{(6)}=-5.3, p<0.001\right)$ and $\mathrm{PH}\left(t_{(7)}=-5.31, p<\right.$ $0.001)$. However, there was no significant differences of diversity of amphibian between MDH and $\operatorname{LDH}\left(t_{(286)}=0.47\right.$, $p=0.634)$, between $\mathrm{LDH}$ and $\mathrm{PH}\left(t_{(174)}=-0.53, p=0.597\right)$, nor $\mathrm{PH}$ with $\mathrm{MDH}\left(t_{(240)}=-0.07, p=0.944\right)$. Low disturbance habitat had the lowest evenness $(0.45)$ caused by the high abundance of Limnonectes modestus. The pattern was similar for reptile, there was a significant differences of Shannon diversity index between $\mathrm{HDH}$ with $\mathrm{LDH}\left(t_{(15)}=\right.$ -6.85, $p<0.001), \operatorname{MDH}\left(t_{(13)}=-6.99, p<0.001\right)$ and
$\mathrm{PH}\left(t_{(17)}=-5.31, p<0.001\right)$. There was no significant differences of diversity of reptile between MDH and LDH $\left(t_{(78)}=-0.21, p=0.833\right)$, between LDH and $\mathrm{PH}\left(t_{(74)}=1.69, p=\right.$ $0.095)$, nor PH with MDH $\left(t_{(62)}=1.60, p=0.114\right)$. Evennes values in all habitats was quite high $(0.63$ in $\mathrm{LDH}$ to 0.79 in $\mathrm{MDH}$ ) because no species dominated in all locations.

For both amphibian and reptile, HDH had the highest differences of species composition with other habitats. Although there were no significant differences between diversity indices in $\mathrm{MDH}, \mathrm{LDH}$ and $\mathrm{PH}$, the composition between those habitats differs (Figure 4). Low disturbance habitat and medium disturbance habitat had 54\% similarities, and together they had $50 \%$ similarities with pristine habitat. For reptiles, pristine habitat and moderate disturbance habitat had $32 \%$ similarities, and together they only had $23 \%$ similarities with low disturbance habitat. Figure 5 shows how composition changes along anthropogenic disturbances. 
Table 2 Reptile species of the Nantu Forest and its adjacent areas, Gorontalo. Red List classifications follow the criteria of IUCN (IUCN 2020): CR = Critically Endangered; EN = Endangered; VU = Vulnerable; NT = Near Threatened; LC = Least Concern; DD = Data Deficient; NE = not evaluated by the IUCN; Endemic [Y/N/? ] = species considered an endemic from Sulawesi; Habitat encountered = habitat where we encountered the species; abbreviations used: $\mathrm{PH}=$ Pristine habitat; $\mathrm{LDH}=$ Low disturbed habitat; $\mathrm{MDH}=$ moderate disturbance habitat (mixed coconut-corn plantation); HDH = high disturbed habitat (Rice Field and Village).

\begin{tabular}{|c|c|c|c|}
\hline Species & $\begin{array}{c}\text { IUCN red list } \\
\text { category }\end{array}$ & Endemic & $\begin{array}{c}\text { Habitat } \\
\text { encountered }\end{array}$ \\
\hline \multicolumn{4}{|l|}{ Agamid Lizard/Agamidae } \\
\hline Bronchocela cristatella (Kuhl, 1820) & $\mathrm{NE}$ & $\mathrm{N}$ & $\mathrm{MDH}$ \\
\hline \multicolumn{4}{|l|}{ Geckoes/Gekkonidae } \\
\hline Cyrtodactylus jellesmae (Boulenger, 1897) & $\mathrm{NE}$ & Y & LDH, PH \\
\hline Gehyra mutilata (Wiegmann, 1834) & $\mathrm{NE}$ & $\mathrm{N}$ & $\mathrm{HDH}$ \\
\hline Gekko monarchus (Schlegel, 1836) & $\mathrm{NE}$ & $\mathrm{N}$ & $\mathrm{PH}$ \\
\hline Hemidactylus frenatus Dumeril \& Bibron, 1836 & $\mathrm{LC}$ & $\mathrm{N}$ & $\mathrm{HDH}, \mathrm{MDH}$ \\
\hline Hemiphyllodactylus typus Bleeker, 1860 & $\mathrm{LC}$ & $\mathrm{N}$ & $\mathrm{LDH}$ \\
\hline \multicolumn{4}{|l|}{ Monitor lizards/Varanidae } \\
\hline Varanus salvator (Laurenti, 1768) & $\mathrm{LC}$ & $\mathrm{N}$ & $\mathrm{LDH}$ \\
\hline \multicolumn{4}{|l|}{ Skinks/Scincidae } \\
\hline Emoia caeruleocauda (De Vis, 1892) & $\mathrm{LC}$ & $\mathrm{N}$ & $\mathrm{MDH}, \mathrm{LDH}$ \\
\hline Eutropis rudis (Boulenger, 1887) & $\mathrm{NE}$ & $\mathrm{N}$ & MDH, LDH, PH \\
\hline Lamprolepis cf smaragdina & $\mathrm{NE}$ & $\mathrm{N}$ & $\mathrm{PH}$ \\
\hline Lipinia quadrivittata (Peters, 1867) & $\mathrm{LC}$ & $\mathrm{N}$ & $\mathrm{LDH}$ \\
\hline Lygosoma bowringii (Günther, 1864) & $\mathrm{NE}$ & $\mathrm{N}$ & LDH, PH \\
\hline Sphenomorphus variegatus (Peters, 1867) & $\mathrm{NE}$ & $\mathrm{N}$ & $\mathrm{LDH}$ \\
\hline Sphenomorphus undescribed sp.1 & $\mathrm{NE}$ & Y? & $\mathrm{PH}$ \\
\hline Sphenomorphus undescribed $s p .2$ & $\mathrm{NE}$ & Y? & $\mathrm{PH}$ \\
\hline \multicolumn{4}{|l|}{ Snakes } \\
\hline \multicolumn{4}{|l|}{ Colubridae } \\
\hline Boiga dendrophila (Boie, 1827) & $\mathrm{NE}$ & $\mathrm{N}$ & $\mathrm{MDH}, \mathrm{LDH}$ \\
\hline Boiga irregularis (Bechstein, 1802) & $\mathrm{LC}$ & $\mathrm{N}$ & $\mathrm{LDH}$ \\
\hline Chrysopelea paradisi celebensis Mertens 1968 & $\mathrm{LC}$ & $\mathrm{Y}$ & $\mathrm{LDH}$ \\
\hline Dendrelaphis pictus (Gmelin, 1789) & $\mathrm{NE}$ & $\mathrm{N}$ & MDH, LDH \\
\hline Lycodon stormi Boettger, 1892 & $\mathrm{NE}$ & Y & LDH \\
\hline Psammodynastes pulverulentus (Boie, 1827) & $\mathrm{NE}$ & $\mathrm{N}$ & $\mathrm{MDH}, \mathrm{PH}$ \\
\hline Ptyas dipsas (Schlegel, 1837) & DD & $\mathrm{Y}$ & $\mathrm{LDH}$ \\
\hline Rhabdophis callistus (Günther, 1873) & $\mathrm{NE}$ & $\mathrm{Y}$ & MDH, LDH \\
\hline Rhabdophis chrysargoides (Günther, 1858) & DD & $\mathrm{N}$ & $\mathrm{MDH}, \mathrm{PH}$ \\
\hline \multicolumn{4}{|l|}{ Cylindrophiidae } \\
\hline Cylindrophis melanotus Wagler, 1828 & $\mathrm{NE}$ & $\mathrm{Y}$ & $\mathrm{MDH}$ \\
\hline \multicolumn{4}{|l|}{ Gerrhopilidae } \\
\hline Gerrhopilus ater (Schlegel, 1839) & $\mathrm{NE}$ & $\mathrm{N}$ & MDH \\
\hline \multicolumn{4}{|l|}{ Pythonidae } \\
\hline Malayopython reticulatus (Schneider, 1801) & $\mathrm{LC}$ & $\mathrm{N}$ & $\mathrm{MDH}$ \\
\hline \multicolumn{4}{|l|}{ Viperidae } \\
\hline Tropidolaemus subannulatus (Gray, 1842) & $\mathrm{LC}$ & $\mathrm{N}$ & $\mathrm{LDH}$ \\
\hline Tropidolaemus wagleri (Boie, 1827) & $\mathrm{LC}$ & $\mathrm{N}$ & MDH, LDH, PH \\
\hline
\end{tabular}


Our study corroborated Iskandar and Tjan's (1996), Setiadi et al. (2011), and Koch (2011) hypothesis that Sulawesi is an important habitat for amphibian and reptiles, some with unique natural histories. The unidentified species of Limnonectes were later described as Limnonectes larvaepartus (Iskandar et al., 2014). The reproductive biology of this frog is distinct to other species, i. e., female frogs gives birth to tadpole instead of releasing eggs to open water (Iskandar et al., 2014; Kusrini et al., 2015).

Compared to other previous research in Sulawesi, the number of species, especially for reptile is relatively low. Gillespie et al. (2005) reported 12 species of amphibian and 55 species of reptile in Lambusango Wildlife Reserve and its

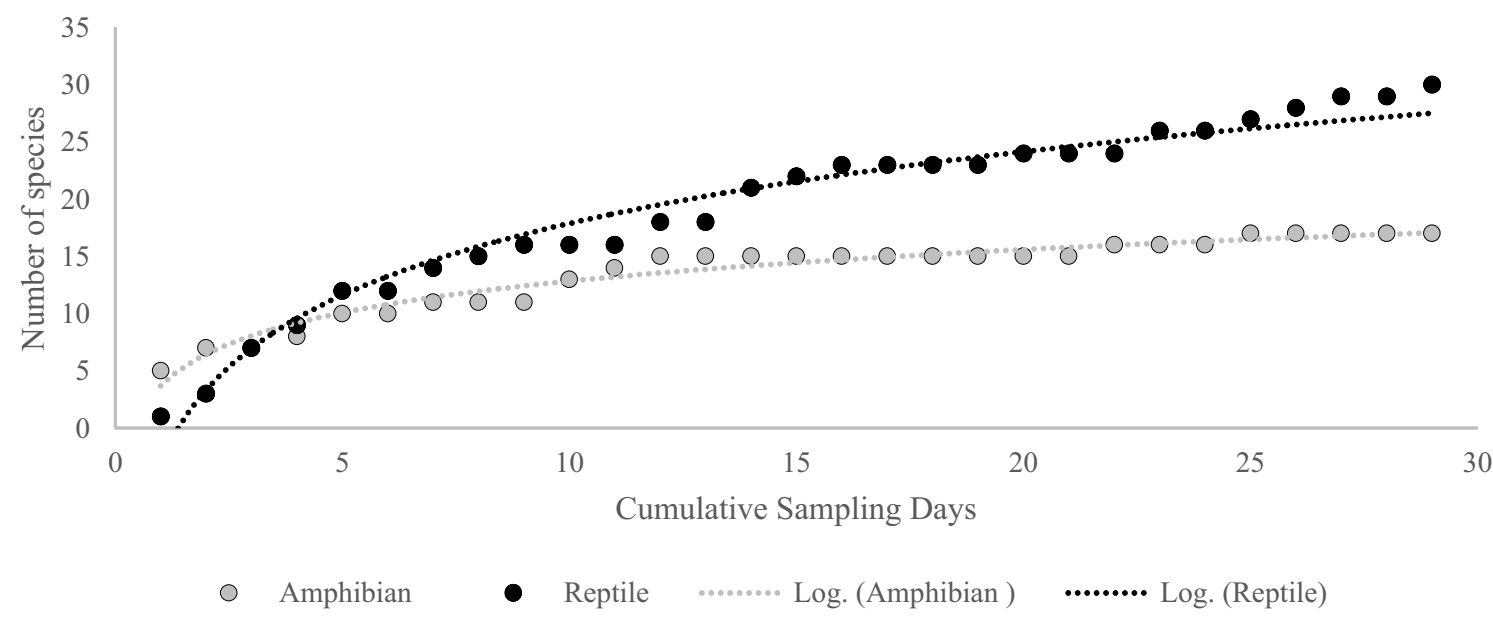

Figure 2 Species-accumulation curves for amphibians and reptiles surveys in Nantu Forest and its adjacent areas, Gorontalo. Cumulative sampling days are the two survey periods (2013 and 2014) combined in sequence.

Table 3 Summary of amphibians and reptiles' community metrics in high disturbed habitat (HDH), medium disturbed habitat $(\mathrm{MDH})$, low disturbed habitat $(\mathrm{LDH})$ and pristine habitat $(\mathrm{PH})$ in Nantu Forest and its adjacent areas. Relative abundance (number of individuals/meter or $\mathrm{n} / \mathrm{m}$ )* is based on stream transect data from the second year only. Species observed (Sobs) is based on result of survey. Estimate of species (Sest) based on Chao-1.

\begin{tabular}{lcccc}
\hline Measure & $\begin{array}{c}\text { High disturbed } \\
(\mathrm{HDH})\end{array}$ & $\begin{array}{c}\text { Moderate disturbed } \\
(\mathrm{MDH})\end{array}$ & $\begin{array}{c}\text { Low disturbed } \\
(\mathrm{LDH})\end{array}$ & $\begin{array}{c}\text { Pristine } \\
(\mathrm{PH})\end{array}$ \\
\hline Amphibians & 0 & & 118.7 & 22.3 \\
Relative abundance (n/m)* & 2 & 41 & 15 & 12 \\
Sobs & 2 & 14 & 16 & 12 \\
Sest & 0 & 14 & 66.7 & 75 \\
\%Sendemic & 0 & 60 & 47.3 & 66.3 \\
\%Abundance of endemic species & 0.45 & 38.8 & 1.92 & 1.97 \\
Species diversity (H') & 0.78 & 1.97 & 0.45 & 0.60 \\
Species evennes (E) & & 0.51 & & 6 \\
\hline Reptiles & 0 & & 8 & 11 \\
Relative abundance (n/m)* & 2 & 7.7 & 17 & 16 \\
Sobs & 2 & 13 & 22 & 27.3 \\
Sest & 0 & 18 & 29.4 & 15.2 \\
\%Sendemic & 0 & 15.4 & 19.6 & 1.98 \\
\%Abundance of endemic species & 0.38 & 2.33 & 2.38 & 0.66 \\
Species diversity (H') & 0.73 & 0.79 & 0.63 & \\
Species evennes (E) & & & & \\
\hline
\end{tabular}


surrounding area (Buton Island, Southeast Sulawesi) whereas Wanger et al. (2011) reported 25 species of amphibian and 54 species of reptile in Lore Lindu National Park. The difference might be caused by the duration of survey. Both Gillespie et al. (2005) and Wanger et al. (2011) conducted their research repeatedly over three years.

There was a clear difference of composition of amphibian and reptiles between different types of land affected by human disturbance (Figure 5 and Figure 6). High disturbance habitat, i.e. rice paddy field has the lowest diversity, with only two species of amphibians (Duttaphrynus melanostictus and Fejervarya cancrivora) and two species of reptiles (Gehyra mutilata and Hemidactylus frenatus) present. These species are tolerant to human impact (Iskandar, 1998) and their distribution have been assisted by human (Church, 1960; Iskandar, 1998). In moderate disturbance habitat, i.e. mixed coconut and corn plantations, number of species increase but mostly dominated by species adapted to human dominated landscape such as Ingerophrynus celebensis, Fejervarya limnocharis and Emoia caerulocauda. Stream surveys in second year yield more species than first year sampling, however, no additional species were found in high disturbance habitat.

The diversity of amphibian and reptile in moderate disturbance, low disturbance and pristine habitat is nearly similar but differ in the composition. Low disturbance habitat and pristine habitat has the highest
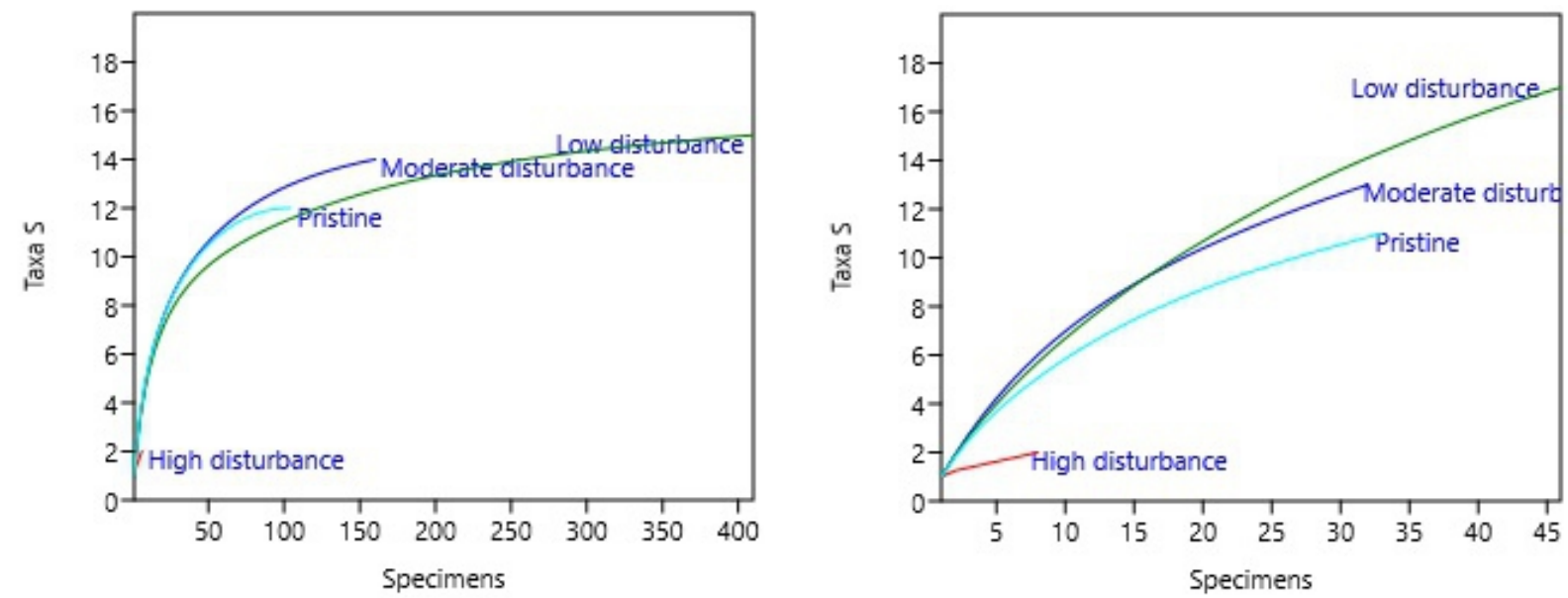

Figure 3 Observed species richness (Taxa S), calculated by sample-based rarefaction curves and scaled to show the number of individuals (specimens) on the $\mathrm{x}$-axis for amphibians (left) and reptiles (right) across habitat disturbance gradient.

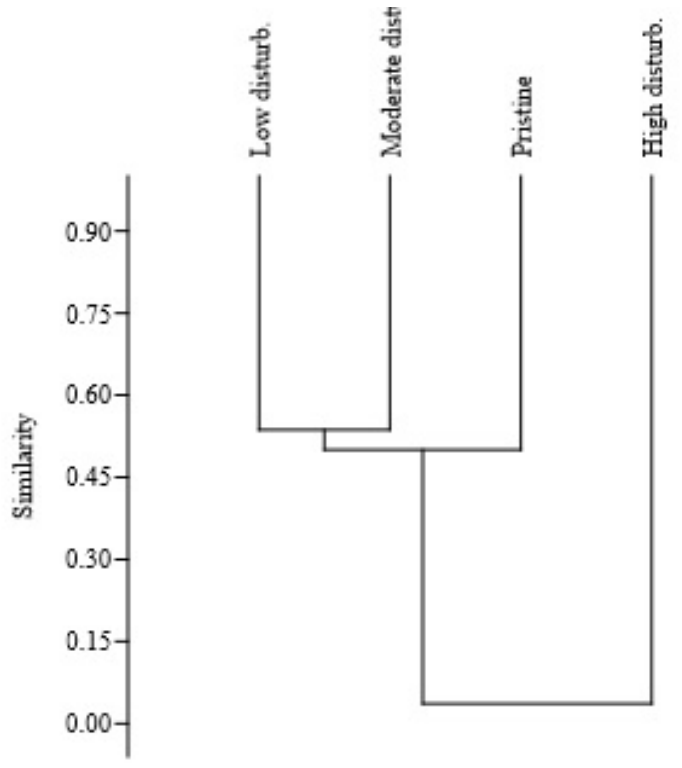

Amphibians

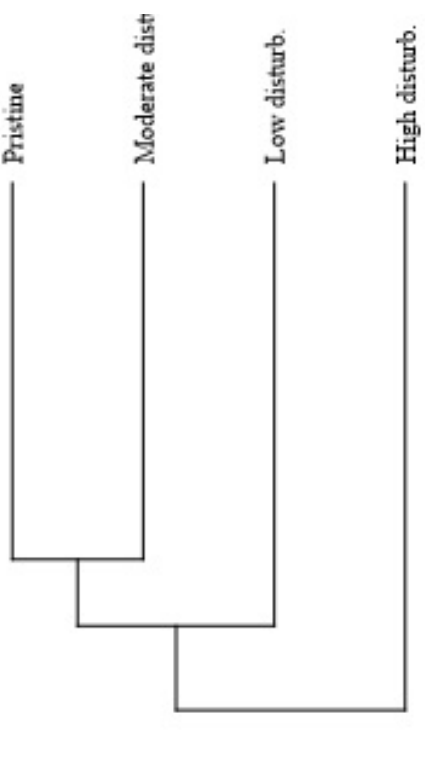

Reptiles

Figure 4 Dendrogram of Bray-Curtis's coefficient of similarity across habitat with different disturbances gradient based on amphibian species composition (left) and reptiles (right). 

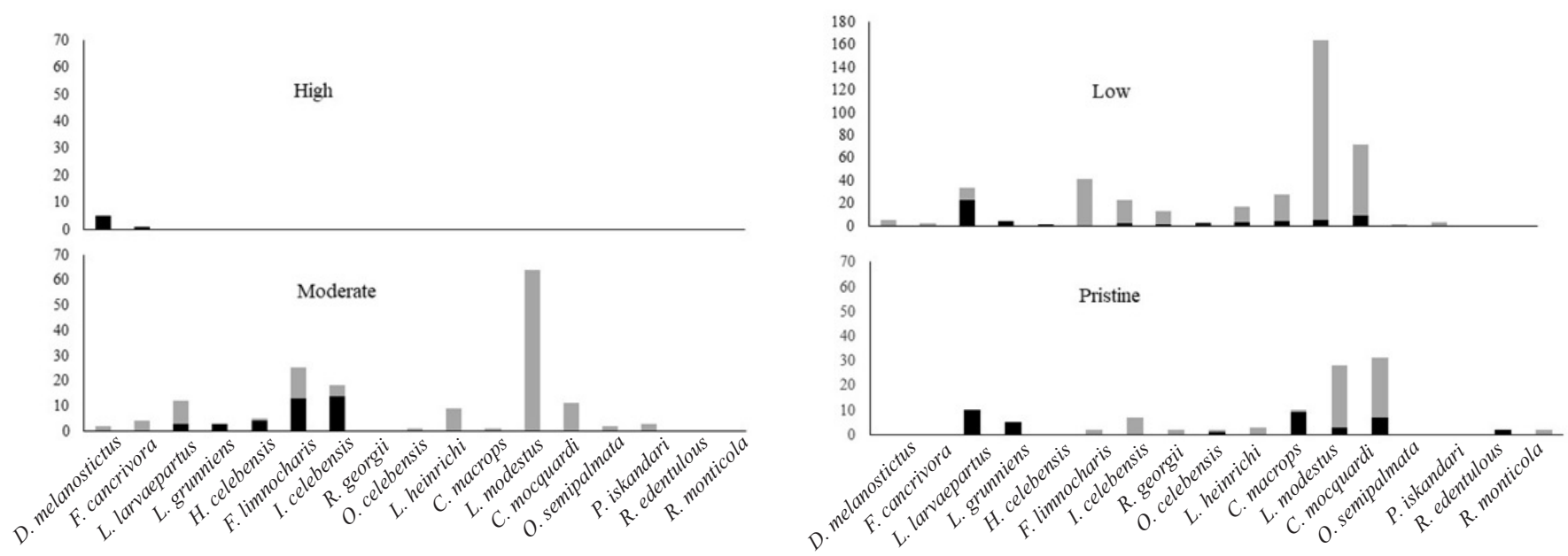

- 2013

= 2014

Figure 5 Change of amphibians' composition along anthropogenic disturbances gradient in Nantu Forest and its adjacent areas from high anthropogenic disturbances (top) to pristine habitat (bottom).
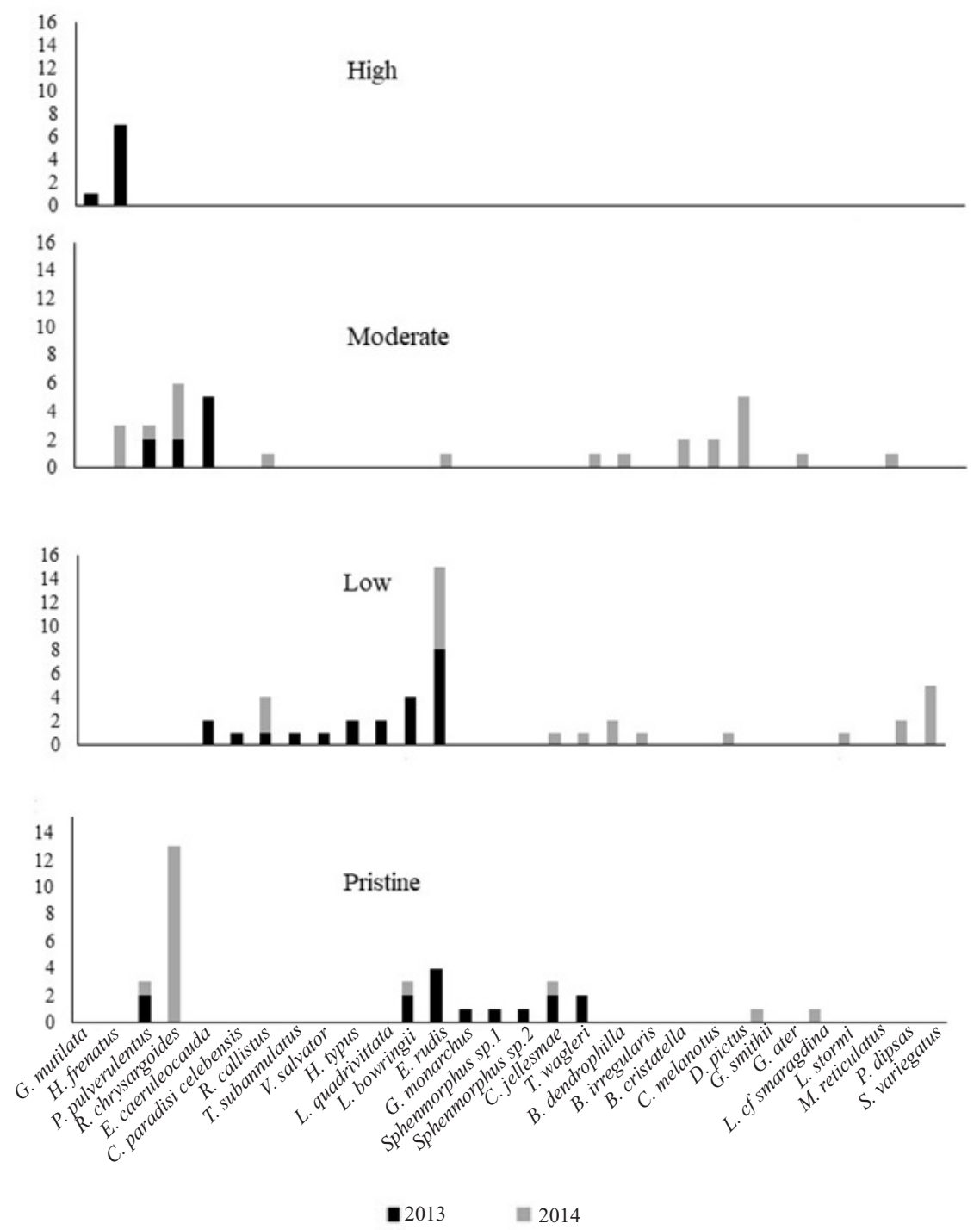

Figure 6 Change of reptiles' composition along anthropogenic disturbances gradient in Nantu Forest and its adjacent areas from high anthropogenic disturbances (top) to pristine habitat (bottom). 
relative abundance of amphibians, as well as percentage of endemic species and bundance of endemic species. The trend is nearly similar for reptiles, although pristine areas has lower relative abundance and lower percentage of endemic species compared to the one in low disturbance habitat. Our study cooroborated Wanger et al. (2010) and Gillespie et al. (2015) that amphibian and reptile richness in Sulawesi is greater in minimally disturbed sites and pristine area than high disturbed sites. However, in contrary to Wanger et al. (2010), our finding did not show that species richness of amphibian decrease from pristine forest to open area. The number of species and abundance for amphibian and reptile is highest in sites with low anthrophogenic disturbance, which supported by the intermediate disturbance hypothesis (Huston, 1979). Huston (1994) suggested that maximum diversity occurs at intermediate level of disturbance. On the other hand, both low disturbance habitat in this study and in Buton (Gillespie et al., 2015) are adjacent to pristine forest which might serve as source of colonization. Protection of forest in Nantu is beneficial for herpetofauna richness. Loss of pristine forest will have caused loss of species, which might be endemic and new to science (i.e. Spenomorphus sp.)

\section{Conclusion}

Anthropogenic pressures in forest will decrease species richness of amphibian and reptiles. Most amphibian and reptile will be able to persist in low disturbances habitat, but forest dependent species, some might be endemics, will be lost when pristine forests are disturbed. Nantu Forest is a hotspot of amphibian and reptile endemic species, therefore monitoring of amphibian and reptiles should be conducted regularly.

\section{Acknowledgment}

We would like to thank our assistants in Gorontalo, Sulawesi, who made this project possible and in particular, the people of Bontula Village for their hospitality and support. Dr. Amir Hamidy from Museum Zoologicum Bogoriense assisted with the identification of specimens. The North Sulawesi Forestry Office (BKSDA Sulawesi Utara) in Manado provided permits and assistance. Permit to conduct the field survey was granted to Luna R. Khairunnisa (23/SIMAKSI/BKSDA-SU/2013), Aria Nusantara (22/SIMAKSI/BKSDA-SU/2013) by the BKSDA on 10 June 2013 and Fata Habiburrahman Faz on 19 May 2014 (18/SIMAKSI/BKSDA-SU/2014). BOPTN DIKTI-IPB Number 2013.089.521219 and BOPTN DIKTI-IPB Number 110/IT3.11/LT/2014 provided funding to MDK, APK, LBP, LRK, AN, FHF. Additional funding from Jodi Rowley through ADM Capital Foundation was provided for fieldwork of LRK and AN. This support is gratefully acknowledged.

\section{References}

Arini, D. I. D., Shabri, S., Kafiar, Y., Tabba, S., \& Kama H.
(2011). Keanekaragaman avifauna beberapa kawasan konservasi Propinsi Sulawesi Utara dan Gorontalo. Manado: Balai Penelitian Kehutanan Manado, Badan Penelitian dan Pengembangan Kehutanan, Kementrian Kehutanan

Austin, K. G., Schwantes, A., Gu, Y., \& Kasibhatla, P. S. (2019). What causes deforestation in Indonesia? Environmental Research Letters, 14(2), 024007. https://doi.org/ 10.1088/1748-9326/aaf6db

Bain, R. H., Lathrop, A., Murphy, R. W., Orlov, N. L., \& Ho, C. T. (2003). Cryptic species of a cascade frog from Southeast Asia: Taxonomic revisions and descriptions of six new species. American Museum Novitate, 3417, 1-60. https://doi.org/10.1206/0003-0082(2003)417< 0001: $\mathrm{CSOACF}>2.0 . \mathrm{CO} ; 2$

Bateman, H. L., \& Merritt, D. M. (2020). Complex riparian habitats predict reptile and amphibian diversity. Global Ecology and Conservation, 22, e00957. https://doi.org/ 10.1016/j.gecco.2020.e00957

Bloom, S. (1981). Similarity indices in community studies: Potential pitfalls. Marine Ecology-Progress Series 5, 125-128. https://doi.org/10.3354/meps005125

Bouvet, A., Paillet, Y., Archaux, F., Tillon, L., Denis, P., Gilg, O., \& Gosselin, F. (2016). Effects of forest structure, management and landscape on bird and bat communities. Environmental Conservation, 43, 148-160. https://doi. org/10.1017/S0376892915000363

Böhm, M., Collen, B., Baillie, J. E. M., Bowles, P., Chanson, J., Cox, N., ..., \& Zug, G. (2013). The conservation status of the world's reptiles. Biological Conservation, 157, 372-385. https://doi.org/10.1016/j.biocon.2012.07.015

Brown, R. M., \& Iskandar, D. T. (2000). Nest site selection, larval hatching, and advertisement calls, of Rana arathooni from Southwestern Sulawesi (Celebes) island, Indonesia. Journal of Herpetology, 34, 404-413. https://doi.org/10.2307/1565364

Brown, R. M., Supriatna, J., \& Ota, H. (2000): Discovery of a new species of Luperosaurus (Squamata; Gekkonidae) from Sulawesi, with a phylogenetic analysis of the genus, and comments on the status of Luperosaurus serraticaudus. Copeia, 2000(1), 191-209. https://doi. org/10.1643/0045-8511(2000)2000[0191:DOANSO] $2.0 . \mathrm{CO} ; 2$

Chao, A., Colwell, R. K., Lin, C. W., \& Gotelli, N. J. (2009). Sufficient sampling for asymptotic minimum species richness estimators. Ecology, 90(4), 1125-1133. https://doi.org/10.1890/07-2147.1

Chape, S., Harrison, J., Spalding, M., \& Lysenko, I. (2005). Measuring the extent and effectiveness of protected areas as an indicator for meeting global biodiversity targets. Philosophical Transactions of the Royal Society B, 360(1454), 443-455. https://doi.org/10.1098/rstb. 2004. 1592 
Che, J., Hu, J. S., Zhou, W., Murphy, R. W., Papenfuss, T. J., Chen, M., ..., \& Zhang, Y. (2009). Phylogeny of the Asian spiny frog tribe Paini (Family Dicroglossidae) sensu Dubois. Molecular Phylogenetics and Evolution, 50, 59-73. https://doi.org/10.1016/j.ympev.2008.10.007

Church, G. (1960). The invasion of Bali by Bufo melanostictus. Herpetologica, 16, 15-21. https://doi. org/10.1016/j.ympev.2006.11.032

Clayton, L. M. (1996). Conservation biology of the babirusa in North Sulawesi, Indonesia [dissertation]. Oxford: University of Oxford.

Clayton, L., Keeling, M., \& Milner-Gulland, E. J. (1997). Bringing home the bacon: A spatial model of wild pig hunting in Sulawesi, Indonesia. Ecological Applications, 7(2), 642-652. https:doi.org/10.2307/2269527

Clayton, L. M., \& Macdonald, D. W. (1999). Social organization of the babirusa (Babyrousa babyrussa) and their use of salt licks in Sulawesi, Indonesia. Journal of Mammalogy, 80, 1147-1157. https://doi.org/10.2307/ 1383165

Clayton, L. M., \& Milner-Gulland, E. J. (1999). The trade in wildlife in North Sulawesi Indonesia. Pages 473-496 In J. G. Robinson, \& E. L. Bennett (Eds.), Hunting for Sustainability in Tropical Forests. New York: Columbia University Press.

Clayton, L. M., Milner-Gulland, E. J., Sinaga, D. W., \& Mustari, A. H. (2000). Effects of a proposed ex situ conservation program on in situ conservation of the babirusa, an endangered suid. Conservation Biology, 14(2), 382-385. https://doi.org/10.1046/j.1523-1739. 2000.99123.x

Cortes, A. M., Ruiz-Agudelo, C. A., Valencia-Aguilar, A., \& Ladle, R. J. (2014). Ecological functions of Neotropical amphibians and reptiles: A review. Universitas Scientiarum, 20(2), 229. https://doi.org/10.11144/Jave riana.SC20-2.efna

Curran, L. M., Trigg, S. N., McDonald, A. K., Astiani, D., Hardiono, Y. M., Siregar, P., ...., \& Kasischke, E. (2004). Lowland forest loss in protected areas of Indonesian Borneo. Science, 303(5660), 1000-1003. https//doi.org/ 10.1126/science. 1091714

de Lang, R., \& Vogel, G. (2006). The snakes of Sulawesi. In J. K. M. Vences, T. Ziegler, \& W. Böhme (Eds.), Herpetologia Bonnensis II. Proceedings of the 13th Congress of the Societas Europaea Herpetologica. Bonn: Societas Europaea Herpetologica.

de Miranda, E. B. P. (2017). The plight of reptiles as ecological actors in the tropics. Frontiers in Ecology and Evolution, 5(159). https://doi.org/10.3389/fevo.2017. 00159

DeWalt, S. J., Maliakal, S. K., \& Denslow, J. S. (2003):
Changes in vegetation structure and composition along a tropical forest chronosequence: implications for wildlife. Forest Ecology and Management, 182, 139-151. https://doi.org/10.1016/S0378-1127(03) 00029-X

Frost, D. R. (2018). Amphibian species of the world: An online reference version 6.0. Retrieved from http://research.amnh.org/herpetology/amphibia/index.h tml.

Gaveau, D. L. A., Curran, L. M., Paoli, G. D., Carlson, K. M., Wells, P., Besse-Rimba, A., ..., \& Leader-Williams, N. (2012). Examining protected area effectiveness in Sumatra: Importance of regulations governing unprotected lands: Evaluating protected area effectiveness. Conservation Letters 5(2), 142-148. https://doi.org/10.1111/j.1755-263X.2011.00220.x

Gaveau, D. L. A., Wandono, H., \& Setiabudi, F. (2007). Three decades of deforestation in southwest Sumatra: Have protected areas halted forest loss and logging, and promoted re-growth? Biological Conservation, 134(4), 495-504.

Gillespie, G. R., Howard, S., Stroud, J. T., Ul-Hassanah, A., Campling, M., Lardner, B., ..., \& Kusrini, M. (2015). Responses of tropical forest herpetofauna to moderate anthropogenic disturbance and effects of natural habitat variation in Sulawesi, Indonesia. Biological Conservation, 192, 161-173. https://doi.org/10.1016/ j.biocon.2006.08.035

Gillespie, G., Howard, S., Lockie, D., Scroggie, M., \& Boeadi. (2005). Herpetofaunal richness and community structure of offshore islands of Sulawesi, Indonesia. Biotropica, 37(2), 279-290. https://doi.org/10.1111/j.17 44-7429.2005.00038.x

Gulson-Castillo, E. R., Pegan, T. M., \& Winarni, N. L. (2018). Sulawesi endemic in the spotlight: First images and sound recordings of the Snoring Rail. Birding ASIA, $30,60-64$.

Hammer, Ø. (2018). PAST PAleontological STatistics version 3.21. Reference manual. Oslo: Natural History Museum University of Oslo.

Hayden, C. J., Brown, R. M., Gillespie, G., Setiadi, M. I, Linkem, C. W., Iskandar, D. T., ..., \& McGuire, J. A. (2008). A new species of bent-toed gecko Cyrtodactylus gray, 1827, (Squamata: Gekkonidae) from the island of Sulawesi, Indonesia. Herpetologica, 64(1), 109-120. https://doi.org/10.1655/07-026.1

Heyer, W. R., Donnely, M. A., McDiarmid, R. W., Hayek, L. C., \& Foster, M. S. (1994). Measuring and monitoring biological diversity: Standard methods for amphibians (M. S. Foster, Ed.). Washington: Smithsonian Institution Press.

Hocking, D. J., \& Babbitt, K. J. (2014). Amphibian contributions to ecosystem services. Herpetological 
Conservation and Biology, 9(1), 1-17.

Howard, S. D., \& Gillespie, G. R. (2007). Two new Calamaria (Serpentes) species from Sulawesi, Indonesia. Journal of Herpetology, 41(2), 237-242. https://doi.org/ 10.1670/0022-1511(2007)41[237:TNCSSF]2.0.CO;2

Howard, S. D., Gillespie, G. R., Riyanto, A., \& Iskandar, D. T. (2007). A new species of Large eutropis (Scincidae) from Sulawesi, Indonesia. Journal of Herpetology, 41(4), 604-610.https://doi.org/10.1670/233-05.1

Huston, M. (1979). A general hypothesis of species diversity. American Naturalist, 113, 81-101. https://doi.org/10.10 $86 / 283366$

Huston, M. A. (1994). Biological diversity: The coexistence of species on changing landscapes. Cambridge: Cambridge University Press.

Iskandar, D. T. (1998). Amfibi Jawa dan Bali. Bogor: Puslitbang Biologi-LIPI.

Iskandar, D. T., Arifin, U., \& Rachmansah, A. (2011a). A new frog (Anura, Dicroglossidae), related to Occidozyga semipalmata Smith, 1927 from the eastern peninsula of Sulawesi, Indonesia. Raffles Bulletin of Zoology, 59(2), 219-228.

Iskandar, D. T., Rachmansah, A., \& Umilaela. (2011b). A new bent-toed gecko of the genus Cyrtodactylus Gray, 1827 (Reptilia, Gekkonidae) from Mount Tompotika, eastern peninsula of Sulawesi, Indonesia. Zootaxa, 2838, 65-78. https://doi.org/10.11646/zootaxa.2838.1.4

Iskandar, D. T., \& Erdelen, W. R. (2006). Conservation of amphibians and reptiles in Indonesia: Issues and problems. Amphibian and Reptile Conservation, 4(1), 60-93. https://doi.org/10.1514/journal.arc.0040016

Iskandar, D. T., Evans, B. J., \& McGuire, J. A. (2014). A novel reproductive mode in frogs: A new species of fanged frog with internal fertilization and birth of tadpoles. PLoS One, 9(12), e115884. https://doi.org/10.1371/journal.po ne. 0115884

Iskandar, D. T., \&Tjan, K. N. (1996). The amphibians and reptiles of Sulawesi, with notes on the distribution and chromosomal number of frogs. In D. J. Kitchener, \& A. Suyanto (Eds.), Proceedings of the First International Conference on Eastern Indonesian-Australian Vertebrate Fauna. (pp. 39-46). Manado, Indonesia.

[IUCN] International Union for Conservation of Nature. (2020). IUCN red list of threatened species. Version 2020-1. Retrieved from http://www.iucnredlist.org.

Koch, A. (2008). Discovery of new specimens of Sarasin's Keelback, Amphiesma sarasinorum (Boulenger, 1896), endemic to SW Sulawesi, Indonesia. Herpetozoa, 20(3/4), 178-182.
Koch, A. (2011). The amphibians and reptiles of Sulawesi: Underestimated diversity in a dynamic environment. In F. E. Zachos, \& J. H. Habel (Eds.), Biodiversity Hotspots (pp. 383-404). Springer.

Kuch, U., Gumprecht, A., \& Melaun, C. (2007). A new species of Temple pitviper (Tropidolaemus Wagler, 1830) from Sulawesi, Indonesia (Squamata: Viperidae: Crotalinae). Zootaxa, 1446, 1-20. https://doi.org/10.52 81/zenodo.176141

Kusrini, M. D., Rowley, J. J. L., Khairunnisa, L. R., Shea, G. M., \& Altig, R. (2015). The reproductive biology and larvae of the first tadpole-bearing frog, Limnonectes larvaepartus. PLoS ONE, 10(1), e116154. https://doi. org/10.1371/journal.pone.0116154

Lassau, S. A., Hochuli, D. F., Cassis, G., \& Reid, C. A. M. (2005). Effects of habitat complexity on forest beetle diversity: Do functional groups respond consistently? Habitat complexity and beetle diversity. Diversity and Distributions, 11(1), 73-82. https://doi.org/10.1111/j.13 66-9516.2005.00124.x

Linkem, C. W., Mcguire, J. A., Hayden, C. J., Setiadi, M. I., Bickford, D. P., \& Brown, R. M. (2008). A new species of bent-toe gecko (gekkonidae:cyrtodactylus) from Sulawesi island, eastern Indonesia. Herpetologica, 64, 224-234. https://doi.org/10.1655/07-040.1

Magurran, A. E. (2010). Measuring biological diversity. Malden: Blackwell Pub.

Margono, B. A., Potapov, P. V., Turubanova, S., Stolle, F., \& Hansen, M. C. (2014). Primary forest cover loss in Indonesia over 2000-2012. Nature Climate Change, 4(8), 730-735. https://doi.org/10.1038/nclimate2277

McDiarmid, R. W., Foster, M. S., Guyer, C., Gibbons, J. W., \& Chernoff, N. (Eds.). (2012). Reptile biodiversity: Standard methods for inventory and monitoring. California: University of California Press.

Moy, M. S., Mardiastuti, A., \& Kahono, S. (2016). Response of Dung Beetle communities (Coleoptera: Scarabaeidae) across gradient of disturbance in the tropical low-land forest of Buton, Sulawesi. Zoo Indonesia, 25(1), 58-70.

Muñoz, J. (2007). Biodiversity conservation including uncharismatic species. Biodiverity Conservation, 16, 2233-2235. https//doi.org/10.1007/s10531-006-9147-1

Prabowo, W. E., Darras, K., Clough, Y., Toledo-Hernandez, M., Arlettaz, R., Mulyani, Y. A., \& Tscharntke, T. (2016). Bird responses to lowland rainforest conversion in Sumatran smallholder landscapes, Indonesia. PLOS ONE, 11, e0154876. https://doi.org/10.1371/journal. pone. 0154876

Robertson, J. M. Y., \& Schaik, C. P. van. (2001). Causal factors underlying the dramatic decline of the Sumatran orang-utan. Oryx, 35(1), 26-38. https://doi.org/10.1046/ 


\section{j.1365-3008.2001.00149.x}

Riyanto, A., Kurniati, H., \& Engilis, Jr. A. (2016). A new bent-toed gecko (Squamata: Gekkonidae) from the Mekongga Mountains, South East Sulawesi, Indonesia. Zootaxa, 4109(1), 59. https://doi.org/10.11646/zootaxa. 4109.1.5

Rowley, J., Brown, R., Bain, R., Kusrini, M., Inger, R., Stuart, B., ..., \& Phimmachak, S. (2009). Impending conservation crisis for Southeast Asian amphibians. Biological Letters, 6(3), 336-338. https://doi.org/ 10.1098/rsbl.2009.0793

Semiadi, G., \& Meijaard, E. (2006). Declining populations of the javan warty pig (Sus verrucosus). Oryx, 40(1), 1-7. https://doi.org/10.1017/S003060530600007X

Setiadi, M. I., McGuire, J. A., Brown, R. M., Zubairi, M., Iskandar, D. T., Andayani, N., ..., \& Evans, B. J. (2011). Adaptive radiation and ecological opportunity in Sulawesi and Philippine fanged frog (Limnonectes) communities. The American Naturalist, 178(2), 221-240. https://doi.org/10.1086/660830

Shah, P., \& Baylis, K. (2015). Evaluating heterogeneous conservation effects of forest protection in Indonesia. PLoS ONE, 10(6), e0124872. https://doi.org/10.1371/ journal.pone. 0124872

Smith, O., Wang, J., \& Carbone, C. (2018). Evaluating the effect of forest loss and agricultural expansion on sumatran tigers from scat surveys. Biological Conservation, 221, 270-278. https://doi.org/10.1016/ j.biocon.2018.03.014

Sodhi, N. S., Posa, M. R. C., Lee, T. M., Bickford, D., Koh, L. P., \& Brook, B. W. (2010). The state and conservation of Southeast Asian biodiversity. Biodiversity Conservation, 19,317-328. https://doi.org/10.1016/j.tree.2005.05.013

Stuart, B. L., Inger, R. F., \& Voris, H. K. (2006). High level of cryptic species diversity revealed by sympatric lineages of Southeast Asian forest frogs. Biology Letters, 2, 470-474. https://doi.org/10.1098/rsbl.2006.0505.

Stuart, S. N., Chanson, J. S., Cox, N. A., Young, B. E., Rodrigues, A. S. L., Fischman, D. L., \& Waller, R. W. (2005). Status and trends of amphibian declines and extinctions worldwide. Science, 306, 1783-1786. https://doi.org/10.1126/science.1103538

Supriatna, J., Shekelle, M., Fuad, H. A. H., Winarni, N. L., Dwiyahreni, A. A., Farid, M., ...., \& Zakaria, Z. (2020). Deforestation on the Indonesian island of Sulawesi and the loss of primate habitat. Global Ecology and Conservation, 24, e01205. https://doi.org/10.1016/j. gecco.2020.e01205

Susanto, E., Lestari, N., \& Hapsari, M. (2018). Driving factors of deforestation in Indonesia: A case of Central Kalimantan. Jurnal Studi Pemerintahan, 9(4), 23. https://doi.org/10.18196/jgp.2018.9390

Uetz, P., \& Hosek, J. (Eds.). (2014). The reptile database. Retrived from http://www.reptile-database.org.

Waltert, M., Mardiastuti, A., \& Mühlenberg, M. (2005). Effects of deforestation and forest modification on understorey birds in Central Sulawesi, Indonesia. Bird Conservation International, 15(3), 257-273. https://doi. org/10.1017/S0959270905000432

Wanger, T. C., Iskandar, D. T., Motzke, I., Brook, B. W., Sodhi, N. S., Clough, Y., \& Tscharntke, T. (2010). Effects of land-use change on community composition of tropical amphibians and reptiles in Sulawesi, Indonesia. Conservation Biology, 24(3), 795-802. https://doi.org/ 10.1111/j.1523-1739.2009.01434.x

Wanger, T. C., Motzke, I., Saleh, S., \& Iskandar, D. T. (2011). The amphibians and reptiles of the Lore Lindu National Park area, Central Sulawesi, Indonesia. Salamandra, 47(1), 17-29.

Whitten, A. J., Mustafa, M., \& Henderson, G. S. (1987). The ecology of Sulawesi. Yogyakarta: Gadjah Mada University Press.

Williams, S. E., Marsh, H., \& Winter, J. (2002). Spatial scale, species diversity, and habitat structure: small mammals in Australian tropical rain forest. Ecology, 83, 1317-1329. https://doi.org/10.2307/3071946

Valencia-Aguilar, A., Cortés-Gómez, A. M., \& RuizAgudelo, C. A. (2013). Ecosystem services provided by amphibians and reptiles in Neotropical ecosystems. International Journal of Biodiversity Science, Ecosystem Services \& Management, 9(3), 257-272. https://doi.org/10.1080/21513732.2013.821168 